\title{
Violencia familiar y rituales afrocubanos en dos obras teatrales de José Triana $(1960,1965)$
}

\section{Familly Violence and Afro-Cuban Rituals in Two Plays by José Triana $(1960,1965)$}

\author{
Rocío Ibarlucía \\ Universidad Nacional de Mar del Plata, Instituto de Humanidades \\ y Ciencias Sociales, Mar del Plata, Argentina \\ Contacto: rocioibarlucia@mdp.edu.ar \\ https://orcid.org/0000-0001-6324-3315
}

\section{RESUMEN}

El dramaturgo cubano José Triana ha publicado obras que escenifican crímenes intrafamiliares cometidos a través de rituales afrocubanos, que exploran al máximo las posibilidades físicas y sonoras de la palabra, dando mayor relevancia a la "poesía del espacio" (Artaud) que al lenguaje verbal. El presente trabajo se propone examinar en Medea en el espejo (publicada en 1960) y La noche de los asesinos (publicada en 1965) las maneras en que la violencia responde a una búsqueda estética de Triana, la cual pone a dialogar el programa de Artaud con las prácticas religiosas africanas. Si bien otros estudios ya han examinado continuidades con el teatro de la crueldad, aún no se ha atendido a los signos de la puesta ni se ha abordado dicha apropiación de Artaud en Medea en el espejo. Mediante un examen del texto dramático y de la virtualidad del texto espectacular, intentaremos observar que estas representaciones de la crueldad pueden ser leídas como un acto de emancipación del poder racista, masculino y occidental. Sus elecciones estéticas -la recuperación del archivo negro, el predominio del cuerpo sobre la palabra y la ambigüedad discursiva- forman parte de una operación política de Triana, quien responde a los debates sobre la función social del teatro mediante obras que se resisten a la homogeneización y la colonización.

Palabras clave: José Triana; Teatro cubano; Violencia familiar; Afrocubanidad; Antonin Artaud

\section{ABSTRACT}

Cuban playwright José Triana has published works that stage domestic crimes committed through Afro-Cuban rituals, which gest explore the physical and sound possibilities of the word, giving greater relevance to "space poetry" (Artaud) than to verbal language. The article aims to analyze in Medea en el espejo (published in 1960) and La noche de los asesinos (published in 1965) the ways in which violence responds to an aesthetic search for Triana, which puts the Artaud's program into dialogue with African religious practices. While other studies have already examined continuities between $L a$ noche de los asesinos and the cruelty theater, the signs of the setting have not yet been addressed and this appropriation of Artaud in Medea en el espejo has not yet been analyzed. By examining the dramatic text and the virtuality of the spectacular text, we will try to observe that these depictions of cruelty can be read as an act of emancipation of racist, male and Western power. Such aesthetic choices - the Afro-American traditions, the body's preponderance over the word and the discursive ambiguity - are part of a political operation by Triana, who responds to debates about the social function of theatre through works that resist homogenization and colonization.

Keywords: José Triana; Cuban Theatre; Family Violence; Afrocubanity; Antonin Artaud 


\section{Introducción}

A lo largo de la historia del teatro cubano, la cultura africana ha sido, o bien excluida de los escenarios, o bien marginada, relegada a papeles secundarios y, sobre todo, caricaturizada por la mirada del explotador blanco. No obstante, es posible reconocer la inclusión de prácticas culturales negras en celebraciones religiosas durante el período de la conquista, su presencia se circunscribe a determinados días del año - las fiestas de Reyes o el Corpus Christi - y a ciertos espacios, como los cabildos, sitios organizados por la Iglesia católica para que los negros puedan desarrollar sus prácticas artísticas y religiosas y, así, reafirmar la estructura social establecida (González, 1997, p. 28). Sin quererlo, estos espacios se constituyeron en verdaderos centros de supervivencia de la religión yoruba -incluyendo su panteón de dioses, sus lenguas, danzas y músicas - y de resistencia cultural (Dos Santos y Dos Santos, 1987, p. 104).

Hacia principios del siglo XIX, el afrocubano logró la categoría de personaje gracias al "padre del teatro cubano" Francisco Covarrubias (1775-1850), quien puso en escena a través de una dramaturgia vernácula y costumbrista la figura del "negrito", que es "representado por actores blancos, para público blanco, actuando en español o en bozal (el idioma parodiado), y, por supuesto, mostrando el punto de vista de la cultura esclavista" (Leal, 1980, p. 30). Su incorporación a la escena teatral, por ende, está marcada por la discriminación étnica y la obediencia al hombre blanco. En la segunda mitad del siglo XIX se consolidó el teatro bufo cubano, definido como un género paródico, popular, caricaturesco, que narra la "historia de las gentes sin historia, esencia de circunstancias, sátira y choteo, sin afán literario, carente del deseo de inmortalidad, escena más que texto, intención más que literatura" (Leal, 1975, p. 23). Desde la cosmovisión blanca, clasista y colonialista, el negro es representado como un esclavo o campesino obediente y bonachón (las obras de Creto Gangá) y, luego, como trabajador libre y urbano que vive "a la blanca" en los suburbios de la ciudad. Según el crítico e historiador teatral cubano Rine Leal,

[e]l esclavismo, que corre por la espina dorsal de nuestra historia, negó las posibilidades de perso- naje dramático al negro, y lo desplazó al bufo, donde tuvo que compartir suertes y percances con la mulata, el chino, el desclasado blanco y el inmigrante pobre, generalmente gallego. Es por eso que el drama "serio", de contenido social, quedó lastrado por el esclavismo y la censura de todo tipo que se ejerció sobre el negro y su expresión artística (1975, p. 49).

A través del teatro se constata la estigmatización de la comunidad afrocubana asociada con la delincuencia, la superstición, la brujería y — si se trata de mujeres - la prostitución. Esa visión racista ha persistido en las composiciones dramáticas locales incluso tras la Revolución de 1959, debido a la promoción por parte de las agencias estatales del teatro bufo como "cultura nacional" y la censura de ciertas obras, como María Antonia (1967) de Eugenio Hernández, que fue cancelada por desviarse de la narrativa revolucionaria sostenida en la redención y ruptura con el pasado, así como en la sustitución de las creencias de raigambre popular y religiosa por la cultura del trabajo. Es destacable la denuncia del equipo de María Antonia, todos afrodescendientes, y de la comunidad negra teatral contra el Consejo Nacional de Cultura por haber elegido a actores blancos con caras pintadas de negro para representar La tragedia del Rey Christophe de Aimé Césaire, en tanto dicha decisión implica denigrar la capacidad de los afrodescendientes para representar la historia por sí mismos (Guerra, 2014, p. 127). Resulta pertinente señalar que la práctica del blackface ha sido aceptada entre los oficiales culturales y aún persiste en el sector turístico y escolar.

Sin embargo, la tendencia a estigmatizar la cultura afro comenzó a resquebrajarse a partir de la década de 1960, gracias a una serie de dramaturgos y directores que apostaron por la recuperación de la memoria afrocubana en las artes escénicas. Uno de ellos fue José Triana (1931-2018), quien rescató prácticas rituales provenientes de la religión yoruba en su dramaturgia posrevolucionaria. Si bien es posible detectar líneas de continuidad respecto del teatro bufo, al mismo tiempo esta estética sufre una actualización al establecer un diálogo con otras poéticas extranjeras, como el teatro de la crueldad de Artaud, cuya propuesta radica en rescatar mitos y cosmovisiones no-occidentales mediante el regreso a la esponta- 
neidad y el salvajismo a fin de huir del pensamiento binario y logocéntrico, propio del teatro burgués de la palabra, la explicación psicológica y la mímesis realista. En el presente trabajo, analizaremos en $\mathrm{Me}^{-}$ dea en el espejo (2004 [1960]) y en La noche de los asesinos (2016 [1965]) la puesta en escena de la violencia, que se construye tanto como tema - ambas obras representan asesinatos intrafamiliares - y también a través de diversos signos de la puesta en escena. Mediante un examen del texto dramático y de la virtualidad del texto espectacular, intentaremos probar que la crueldad responde a una búsqueda estética de Triana, la cual pone a dialogar el programa de Artaud con las prácticas religiosas africanas.

Las dos obras presentan asesinatos, al practicar un filicidio en el caso de Medea en el espejo y un parricidio en La noche de los asesinos, llevados a cabo a través de rituales afrocubanos. La música, la danza y la sonoridad de las palabras intervienen en los sacrificios a sus parientes. Cada uno de estos componentes del espectáculo recupera canciones, instrumentos musicales, palabras y dioses de la cultura africana. Dicha ritualización, que es un eje estructurador de la obra de Triana de acuerdo con Román V. De la Campa (1979), ha sido identificada con los presupuestos de Artaud, en tanto sustituye la representación mimética de la realidad por un teatro que recupera su original acepción religiosa y mística. Las obras, entonces, mediante la recuperación del archivo afroamericano, emplean ese lenguaje físico-material que - para Artaud - es el propio del teatro, puesto que se dirige primero a los sentidos. Se reemplaza, así, la poesía del lenguaje por una poésie dans l'espace (Artaud, 2014, p. 47), configurada no solo a través de la palabra hablada sino de la música, la danza, la plástica y la gesticulación. Los rituales afroamericanos colaboran en la construcción de imágenes físicas violentas que "trituran e hipnotizan la sensibilidad del espectador, capturado en el teatro por un torbellino de fuerzas superiores" (Artaud, 2014, p. 87).

Por tanto, este programa estético no se reduce a exhibir la brutalidad sobre el escenario o aplicar un determinado lenguaje de gestos; por el contrario, conlleva un afán por desestabilizar al espectador y trastornar su percepción de las cosas. Autores como Julio E. Miranda (1969), José A. Escarpenter (1994) y
Jesús Barranco (1997) ya se han ocupado de estudiar las continuidades entre $L a$ noche de los asesinos y el teatro de la crueldad, aunque no han examinado dicha vinculación en Medea en el espejo. Barranco, por ejemplo, propone leer la obra publicada en 1965 como un acontecimiento ritual que, alejado de la estética aristotélica y la mímesis realista, enfrenta al público espectador a un espacio sagrado propicio para el exorcismo, explotado en toda su potencialidad escénica (palabra, imagen, ritmos, antropología actoral). Nuestro trabajo, pues, se propone desarrollar con mayor profundidad las cuestiones señaladas en tales estudios, así como examinar el modo en que se apropia Medea en el espejo de los preceptos de Antonin Artaud. La violencia y la destrucción dentro del seno familiar resulta, de acuerdo con Matías Montes Huidobro, un tema reiterado en la dramaturgia cubana:

[...] pendiente inclinada hacia el odio voraz y sangriento dentro del panorama familiar de teatro cubano, en especial a partir de 1959, que responde a razones permanentes de un lado y a razones locales y temporales del otro debido a la creciente división de la "gran familia cubana" dentro del plano histórico y político. (1973, p. 236)

En efecto, el escritor y crítico cubano señala que las relaciones violentas entre padres e hijos y entre hermanos, así como el incesto, revelan "la división ideológica entre los cubanos, teñida de sangre durante el batistato y el castrismo" (Montes Huidobro, 1973, p. 236). La batalla campal de la gran familia cubana, el afán destructivo hacia el crimen, la lucha entre parientes y la ilusión de liberación a través del crimen son tópicos que este crítico señala sobre otras obras cubanas de los años sesenta, que también pueden ser leídas en las piezas seleccionadas para trabajar en este artículo. Cabe agregar a la interpretación política de Montes Huidobro que el enfrentamiento también revela desigualdades raciales, como intentaremos comprobar.

\section{María, una Medea pobre y mulata enfrentada al poder blanco y colonial}

Medea en el espejo, publicada en 1960, es una reescritura de Medea de Eurípides que pone en tensión la mitología griega y la local, lo que provoca una desterritorial- 
ización de los espacios sagrados del canon clásico. La pieza respeta de cerca la estructura y las unidades aristotélicas del texto fuente, ya que toda la acción transcurre "hace algunos años", en el patio de un solar, desde el mediodía hasta el alba. A su vez, los personajes tienen su correlato con los de Eurípides: Medea-María, Jasón-Julián, Nodriza-Erundina, Glauce-Esperancita, Creonte-Perico Piedra Fina. Ya desde este cambio en los nombres podemos advertir la incorporación de la cultura afrocubana en la tragedia, que se acentúa en la configuración de personajes de raigambre popular y en el uso de un léxico proveniente de diferentes lenguas africanas en sus diálogos, como vocablos de bilongo, lengua lucumí o yoruba (Ortiz, 1975).

Así, se produce un distanciamiento de su sentido primario a través de una deformación de los asuntos solemnes. Los signos de la tragedia de Eurípides se invierten al reemplazar lo erudito por lo vulgar, lo serio por lo risible. María, en lugar de invocar a las diosas de la justicia y de la hechicería Ártemis o Hécate, se santigua con un ramito de albahaca y acude a Madame Pitonisa, una bruja negra que, junto al Doctor Mandinga, le intentan hacer un "buen despojo" tirándole luego, "cae en trance" mediante un desdoblamiento entre el "yo" y la imagen reflejada en el espejo. No se reconoce a sí misma, por lo que asesina a sus propios hijos para recuperar su vida. El hecho de que se emplee la palabra "trance" remite a la posesión de los dioses durante los rituales yorubas; es decir, a María le "baja el santo" o es "montada por una fuerza sobrenatural" (Cabrera, 2009, p. 29), lo que implica que ha tomado posesión de su cuerpo un espíritu, que se comporta como si fuese su dueño durante el tiempo de permanencia en ella. Para la religión yoruba, el trance implica que el santo desaloja o reemplaza al yo del "caballo", empleando las mismas palabras de los practicantes: "el santo baja para montar tu caballo, se mete dentro de este, y ese hombre, o esa mujer, que le entra santo, ya no es quien es: es el santo mismo" (Cabrera, 2009, p. 30). En este caso, luego de envenenar a los amantes, María es poseída por el santo y pierde su conciencia habitual, hasta que se marche. El mito griego se reterritorializa en el contexto afrocubano, a través del rito de posesión usualmente empleado en la religión yoruba y las teorías espiritistas, aunque no será el único momento en que se apropie de estos elementos mágico-religiosos.

\section{La violencia ejercida por María, sobre todo, el asesinato de sus propios hijos, es un acto de rebeldía frente al poder hegemónico, que es blanco, masculino y occidental}

las cartas. Las didascalias a su vez aclaran que varios discursos de María deben ser "solemnes y ridículos al mismo tiempo" o con acento "melodramático", lo que evidencia una "transposición paródica del mito griego" (Lobato Morchón, 2002, p. 230), en tanto la tragedia se contamina de la comedia a fin de generar un efecto de comicidad. El conflicto trágico sufre, entonces, un proceso de degradación a causa de esta yuxtaposición de referencias elevadas con giros irreverentes.

El argumento recupera el conflicto central del texto fuente, aunque sufre ciertas reformulaciones. Si bien María no es extranjera como Medea, igualmente es víctima de la marginación social por ser mujer, mulata y pobre, que vive con sus hijos en un solar de La Habana; su pareja, Julián, un joven blanco y rubio, se casa con la hija de Perico Piedra Fina, el dueño del solar y hombre blanco. Al enterarse de esta traición, María envenena a Esperancita y a Perico y,
Tal distanciamiento de la trama original está ocasionado por una nueva problemática vinculada no ya a la sociedad ateniense, sino a la discriminación racial vigente en la sociedad cubana, por lo que podría leerse que la violencia de María implica una "emancipación racial y cultural" (De la Campa, 1979, p. 15) respecto de la opresión ejercida por los personajes blancos. Esta dimensión racial es resaltada por el autor a través del dramatis personae, donde cada uno es descripto a partir de su procedencia étnica ("mulata", "negra", "mestiza", "rubio", "blanco", etc.). José Escarpenter (1994) sostiene que, en la obra, los personajes blancos - Julián y Perico Piedra Fina - son la casta dominante, por lo que desencadenan la acción a través de la detentación de poder, mientras que los mulatos y negros se relegan a la posición de víctimas de la arbitrariedad y, en lugar de buscar la lucha social, ejercen la venganza apoyada en sus creencias religiosas. No obstante, es 
pertinente señalar que el racismo es denunciado en boca de los personajes en una ocasión: el barbero comenta que los negros no pueden oponer resistencia a Perico, quien hace acatar sus órdenes como si fuesen "leyes con sello oficial", a lo que una mujer le responde: "En este país tener el pellejo prieto es una desgracia" (Triana, 2004, p. 100). Por ende, María, dada su condición de mujer mulata, no tiene opción: debe irse del solar con sus hijos por orden de Perico, a quien el coro lo denomina "una especie de inquisidor", pues ni en tiempos de la colonia "jamás se mantuvo una situación tan alarmante" (Triana, 2004, p. 99). La violencia ejercida por María, sobre todo, el asesinato de sus propios hijos, es un acto de rebeldía frente al poder hegemónico, que es blanco, masculino y occidental.

En relación con esta lectura, el filicidio practicado por María también se produce a través de un ritual, práctica religiosa proveniente de la cultura afrocubana que se presenta en diferentes instancias de la obra. Primero, tres mujeres - María, mulata; Erundina, negra; y la Señorita Amparo, mestiza - realizan un embrujo bajo la métrica del tambor. La Señorita recita un discurso premonitorio del crimen:

SEÑORITA. (Mecánica.) En la calle, en la plaza, en el parque, en la bodega, en el cine, en el café, en la guagua, Chencha la gamba, Rosa la China, Cachita Burundanga, la mujer de Antonio, la mujer de Pedro, la de Chucho, la de Jacinto, la de José, me han dicho, me dijeron, están diciendo, que eres, que eras, que serás, que siempre, que ahora, que nunca, que jamás, que estás, que estabas, que estarás, en la esquina de este solar sin nombre esperando al llamado de la sangre. (Triana, 2004, p. 98)

Este parlamento se produce mientras "Las tres mujeres quedan enlazadas y comienzan a moverse rítmicamente" y, como especifica la didascalia, la "escena debe mantener un ritmo de son". La dimensión rítmica se produce gracias al despliegue de un repertorio de procedimientos que otorgan un vasto número de pulsiones rítmicas. Debido al uso de figuras de dicción — paralelismo sintáctico, anáfora, repetición léxica-, este texto se construye entre los lindes de la poesía y la música. Su tratamiento peculiar de lo auditivo es propio de los motivos del son, género mu- sical cubano cuya estructura se basa en la repetición rítmica y también verbal. A su vez, la aliteración otro recurso rítmico propio del son - provocada por la reiteración de los fonemas "ch" — "Chencha la gamba, Rosa la China, Cachita Burundanga"-, así como "mb", "ng" y "k", genera sonidos cercanos a los golpes percusivos, como el que emite un tambor. Además, la repetición de la misma palabra y la separación entre comas conducen a una lectura y escucha semejante al compás medido y constante. Por ende, el rescate de la cultura afrocubana se construye desde un plano temático y también formal, en especial a partir de imágenes auditivas.

Los versos trágicos también tenían un ritmo particular gracias a su métrica, lo que generaba una mayor preponderancia de lo auditivo frente a lo visual. En ese caso, ello se debía al principio del decoro, que evitaba mostrar ante los ojos del espectador las escenas violentas. En la obra de Triana, en cambio, lo auditivo cumple otra funcionalidad, inmediatamente vinculada con la religión practicada por los afrodescendientes. En efecto, los cultos lucumí o santerías presentan un acervo polirrítmico, cuya ejecución es realizada por solistas, coros vocales y grupos instrumentales constituidos por una amplia variedad de tambores, güiros, maracas, cencerros, entre otros, aunque sobresale la singularidad del llamado "rezo por su belleza lírica y clímax sonoro" (Urfé, 1987, p. 220). Dicha exploración rítmica de la palabra puede vincularse también con la desarticulación del lenguaje promovida por Artaud, quien, al desconfiar de su poder significante, promueve la reubicación de la palabra en una nueva posición, cercana al encantamiento mágico y mítico. Recuperar el poder de acción del lenguaje conlleva, para el teatro de la crueldad, recrear y extender los límites de la realidad. Los diálogos entre las tres mujeres evidencian un uso performativo del lenguaje, en tanto la palabra es un vehículo de la sangre, es decir, "se pronuncia una palabra para llegar con ella al crimen”, según Montes Huidobro (1973, p. 246). Si bien este crítico cubano examina las obras de Triana desde una lectura "esquizofrénica", es posible trazar un diálogo con el poder evocador de la palabra en el teatro de la crueldad y, al mismo tiempo, con el meticuloso diseño sonoro propio de los cantos rituales africanos. 
Esta preponderancia de la prosodia no aparece en todos los discursos de los personajes, sino en boca de negros o mulatos; además, se proclaman en momentos en que practican un ritual de la religión afrocubana. De este modo, la tragedia griega se resemantiza al incorporar la historia de Medea en un nuevo continente y, en consecuencia, sufre una desacralización en el nivel textual y también en la puesta en escena: la música es acompañada por una danza peculiar y por acciones físicas que están al servicio de la invocación a los dioses yorubas. Por ejemplo, Madame Pitonisa y el Doctor Mandinga tiran caracoles en el suelo, albahaca y rompezaragüey, como si santiguaran el escenario. Mientras esparcen los polvos, invocan a los espíritus infernales diciendo:

MADAME. [...] A través del mal en esta tierra, en este infierno, el sufrimiento, la purificación... A través del mal..., la tierra... A través del mal..., el infierno... A través del mal en esta tierra, en este infierno [...] (Se detiene en el centro del escenario, gira dos veces sobre sí misma. El doctor Mandinga está en el fondo del escenario, resoplando y pronunciando palabras ininteligibles.) Acércate, espíritu purificador... (Vuelve o girar sobre si misma. Pausa. En trance.) Por los nueve demonios... (El DOCTOR MANDINGA da tres patadas misteriosas en el suelo.) Por los nueve demonios que asisten cada ventana. (Triana, 2004, p. 116)

Este exorcismo, caracterizado por la desarticulación del cuerpo y la palabra y por la consecución de un estado fronterizo entre lo divino y lo humano, también responde a los presupuestos de Antonin Artaud, en tanto recupera la original acepción religiosa y mística del teatro. Mediante la incorporación de tradiciones culturales de origen africano, Medea en el espejo emplea ese lenguaje físico-material que, para Artaud, es el propio del teatro puesto que se dirige primero a los sentidos. Esto es, el ritual colabora en la construcción de imágenes físicas violentas que "trituran e hipnotizan la sensibilidad del espectador, capturado por un torbellino de fuerzas superiores" (Artaud, 2014, p. 87). Por tanto, apropiarse de este programa estético no se reduce a un determinado lenguaje de gestos; por el contrario, conlleva un afán por desestabilizar al espectador y trastornar su percepción de las cosas.
Ya en el mito de Medea se alude a la tradición de la brujería y las creencias "supersticiosas" a través del uso de plantas medicinales y conocimientos alternativos para conseguir que Jasón se apropie del vellocino de oro, a pesar de que ello implique enfrentarse a su padre, matar a su hermano y abandonar su ciudad. Cuando Jasón la abandona por Glauce, Medea usa la magia para matarla a ella y a Creonte. La relación entre Medea y la brujería es retomada por Triana, aunque este vínculo se resignifica al inscribir a dicho personaje en la religión afrocubana, como se ve en el asesinato de Esperancita, Perico Piedra Fina y el de sus propios hijos. En tal caso, los negros Madame Pitonisa y el Doctor Mandinga llevan a cabo una ceremonia que se vincula más con la magia negra practicada por

[...] la Regla de Mayombe o de Palo de Monte o Kimbisa, proveniente de la región oriental de Cuba - cuya población es mayoritariamente descendiente de los bantúes del Congo y Angola-, que con los ritos yorubas propios de la zona occidental donde ocurre la acción. (Escarpenter, 1994, p. 34)

Ello es reconocible por la presencia de las fuerzas de la naturaleza y la concepción animista, que le otorga a las plantas y a los animales poderes sobrenaturales que responden al imperio de las deidades. El uso de yerbas como la albahaca en ceremonias religiosas es frecuente en tanto las plantas están dotadas de poderes mágicos de un santo o fuerza sobrenatural, como señala Lydia Cabrera en El monte (2009). Si bien se emplean como antídoto contra una dolencia y enfermedad, su uso puede causar el bien o el mal según la intención de quien lo utiliza (Cabrera, 2009, p. 22). Es el rito, su palabra y su conminación mágica, el que determina su efecto: o se hace para liberar de una mala sombra, de una influencia maléfica de un ñeque, o para producir daño: "El palo hace lo que se le mande" (Cabrera, 2009, p. 22). Por ende, una zona de contacto entre María y Medea es que ambas son discriminadas por llevar a cabo estas prácticas alternativas opuestas a la cultura oficial, y en consecuencia son acusadas de locas por el resto de los personajes.

$\mathrm{Al}$ igual que en la tragedia griega, el asesinato de los hijos no ocurre ante los ojos del espectador, sino 
que se comunica a través del coro, que solemne y casi cantando exclama: "Sangré sangré sangré sangré / No te hundas en la sangre / Sangré sangré sangré sangré / No te hundas en la sangre / Sangré sangré sangré sangré / Ay sangre ay perdición" (Triana, 2004, p. 123). Los textos del coro nuevamente se pronuncian bajo una métrica compuesta por versos octosílabos, es decir, un molde de raigambre popular y oral. La obra culmina con la lucha desesperada entre el coro y María, quien grita salvajemente: "Soy Dios" (Triana, 2004, p. 124), mientras el coro horrorizado la levanta como un trofeo. Esta frase nos lleva a trazar una comparación con el final de Medea de Eurípides. En la obra clásica, la heroína trágica, al ser hija del dios Hermes, puede escapar con los cuerpos de sus hijos muertos en un carro alado, empleando el recurso de deus ex machina. Su procedencia divina la salva de la venganza de Jasón. En el texto cubano, la propia María se erige en una especie de diosa, frente al coro que la juzga de asesina. Sin embargo, este final sufre un quiebre respecto de la obra original en tanto puede ser interpretado desde una clave, por un lado, existencialista y, por otro, religiosa.

Para comprender la adscripción de la obra de Triana al existencialismo, cabe detenerse en otro desplazamiento del texto original: el título Medea en el espejo, tanto como hace explícito el diálogo intertextual con la tragedia griega, alude también al espejo, objeto cargado de simbolismo que se va resignificando a lo largo de la obra. En un principio, aparece cada vez que María se pregunta por su propio destino. $\mathrm{Al}$ ver su imagen reflejada percibe la existencia de dos Marías, la que está dentro y la que está fuera del espejo:

Es necesario que me levante contra esa María que me arrastra y me humilla. (Se levanta.) Ya sé que no son los otros; eres tú, María, quien me empuja al vacío. Tú eres mi enemiga. Yo soy la otra, la que está en el espejo, la que estaba esperando y tenía miedo y no quería salir y se escapaba y no veía que estaba sola. (Triana, 2004, p. 121)

Este desdoblamiento expone cómo María ha aparentado ser algo que no es - una gran señora- $y$, por ende, se ha condenado a una existencia enajenante, actuada y sometida. El espejo, pues, le permite reco- brar su vida, dejar atrás las ataduras y asumir su propia libertad, aunque aquello implique la soledad:

[...] yo soy yo; que ya no me importan ni el bien ni el mal, que toda esa patraña la he borrado; ahora soy; [...] necesito la vida, sí, la vida: en el horror; en la sangre, en la ternura, en la indiferencia, en el crimen. (Triana, 2004, p. 121)

A través del asesinato de los hijos, María logra liberarse del encierro y encontrarse a sí misma. En este momento de autorreconocimiento o anagnórisis, ve aparecer una multitud de espejos en el escenario y decide cometer el crimen para poder exclamar, finalmente, "Soy Dios". De acuerdo con Ricardo Lobato Morchón (2002), Triana inscribe sus obras en el existencialismo, corriente que atraviesa las creaciones del absurdo europeo y también cubano. De hecho, Triana, como Piñera, Arrufat y Dorr, dejaron manifiesto este interés en la revista Ciclón. En tal caso, María es - al igual que otros personajes de obras existencialistas un sujeto despersonalizado que lucha contra el automatismo y la simulación impuestos por la condena social a fin de recobrar su individualidad a través de actos cometidos por decisión personal, libre y creadora.

No obstante, cabe señalar que en algunas religiones afrocubanas el espejo es un objeto empleado "para averiguar el paradero de una persona ausente" (Ortiz, 1995, p. 113). María lo usa para buscar a la amante, pero también para buscarse a ella misma, como observa Escarpenter, por lo que el uso de este objeto también tiene una fuerza religiosa. De igual modo, la expresión "Soy Dios" puede ser interpretada como parte del rito de posesión de las prácticas religiosas afrocubanas. Asesinar a la amante implica desterrar al representante de la autoridad en el plano familiar (el padre) y en el plano político (el cacique), pero también en el plano religioso (Dios); este último puede leerse a partir de su afirmación final "Soy Dios". El crimen es una matanza de los dioses preexistentes, cuya crueldad e indiferencia perpetuadoras de la desigualdad étnica debe ser sustituida por la creación de nuevos dioses. Ella misma se convierte en un nuevo dios, instaura una nueva religiosidad:

El pueblo cubano parece que necesita dioses. $\mathrm{Al}$ mismo tiempo, cansado de la opresión de los 
mismos, necesita asesinarlos. Por lo menos, este es un péndulo constante dentro del teatro. Dioses necesarios, muerte de los dioses, ocupación del lugar de los dioses, nuevos dioses necesarios... Secuencia cíclica. (Montes Huidobro, 1973, p. 238)

A través de su crimen, logra crear una nueva religiosidad librada de las ataduras de otra religiosidad pasada, injusta, masculina y opresiva. El tema del asesinato de los propios hijos, además de ser tomado de la tragedia Medea, remite a los asesinatos practicados por mujeres negras en tiempos de esclavitud. Ya el político e intelectual haitiano Jean Louis Vastey (1781-1820) señala en 1814, en su libro El sistema colonial develado (2018), ciertos episodios de envenenamiento de mujeres negras esclavas a sus hijos a causa de la miseria, la degradación y la imposibilidad de salir de la deshumanización:

Detractores de los negros, ¿ahora sorprende que nuestras facultades morales y físicas estaban comprimidas por una tan dura esclavitud? ¿Qué sentimientos liberales podían germinar en corazones colmados de oprobio! [...] ¿Sorprende que fuésemos propensos a los suicidios, envenenamientos, y que nuestras mujeres apagaran en sus corazones los dulces sentimientos de la maternidad, matando por una cruel piedad a los queridos y tristes frutos de sus amores? [...] ¿Amar la vida no es una insigne cobardía? Y por qué dar a luz a desafortunados, cuya vida entera estaba condenada a arrastrar su endeble existencia en el oprobio y los tormentos, en una larga sarta de pena sin fin. Apagar una vida tan odiosa, ¿era pues un crimen tan grave? iiiEra compasión, humanidad!!!... (pp. 123-124).

Desde un tono cargado de odio hacia la mirada ignorante del colono blanco, Vastey afirma que el filicidio era una práctica frecuente entre las mujeres esclavas como una medida desesperada y cargada de humanidad para evitar que su progenie sufra las mismas calamidades que ellas. Por ende, destierra la mirada estereotipada y simplificadora de dichos asesinatos, construida por los autores de sus crímenes, es decir, los colonos blancos. Por otro lado, el historiador del Caribe anglófono C.L.R. James también menciona en 1938, en su texto Los jacobinos negros (2003), que los blancos destacaban como prueba contra los negros su tendencia homicida, especialmente a través del envenenamiento de niños, con el fin de persuadir al mundo blanco, haciéndole creer que el esclavo es un animal apenas humano, solo apto para la esclavitud. Como la vida de un esclavo era insoportable, de acuerdo con James la comunidad afrocaribeña pensaba la muerte como una liberación y también como un retorno a África (2003, p. 31).

A partir de los ensayos citados - y sin desconsiderar que sus intervenciones han buscado polemizar con los discursos de su época, en especial, de los colonos y de la historiografía inglesa, respectivamenteconsideramos que Triana resignifica el asesinato de la mitología griega al remitirnos a las prácticas homicidas de las mujeres esclavas, en tanto también para María asesinar a su progenie significa una liberación. La Medea de Triana expone una reformulación de la visión europea presente en el mito clásico al resemantizar el texto dramático y espectacular desde una mirada latinoamericana. María mata a la amante de su esposo, al dueño blanco del solar y a sus hijos como consecuencia de la marginación social y racial sufrida por su condición de mujer, mulata y pobre. La búsqueda de su subjetividad subvierte esa estigmatización y dependencia impuesta por su marido y por Perico Piedra Fina, que la condena a ser un sujeto sin derechos. Al mismo tiempo, podríamos pensar que Triana, a través de la reapropiación del mito de Medea, plantea el problema de la recuperación de la identidad no solo individual, sino también nacional y en términos étnicos, puesto que pone en el escenario a la comunidad afrocubana, históricamente relegada a un segundo plano.

En efecto, el problema de la nación cubana se encuentra en su auge después de la victoria revolucionaria; así es planteado también por otros escritores latinoamericanos que defienden el paradigma de la "transculturación" propuesto por el antropólogo cubano Fernando Ortiz (1987) a fin de estudiar los procesos de intercambio culturales y, a su vez, considerar la tensión nacional entre las culturas locales y la cultura del blanco occidental. Esta nueva concepción de la literatura y el arte latinoamericanos desarrollada en 1960 debe entenderse como una operación de política cultural que lucha contra la homogeneización y la colonización. En rigor, leemos la obra de Triana des- 
de el concepto de "heterogeneidad" (Cornejo Polar, 2003) puesto que, como vimos, presenta una intersección conflictiva entre dos universos socioculturales. Ello se manifiesta en el discurso teatral de Medea en el espejo, donde hay zonas de contacto y de despegue entre la cultura afroamericana y la occidental. Triana, por ende, responde a los debates de la época sobre la función social del teatro y propone un espectáculo que, a pesar de usar la mitología blanca y europea, la pone en tensión con las cosmovisiones del territorio caribeño, sin dejar de indagar sus problemáticas económicas, políticas, sociales y culturales.

\section{Asesinar a los padres, una eterna resistencia a la autoridad}

La noche de los asesinos, estrenada en La Habana en 1966 bajo la dirección de Vicente Revuelta, es la obra de Triana más aclamada por la crítica internacional, ganadora del premio Casa de las Américas en 1965 y traducida a múltiples idiomas. Los estudios cercanos a su publicación destacan los préstamos del théatre de la cruauté; entre ellos, Julio E. Miranda afirma que esta pieza es la más importante del teatro cubano de los años sesenta porque "ha logrado una renovación del lenguaje y la estructura dramática, un uso maestro del absurdo y la crueldad entendidos como instrumentos de investigación de un tiempo absurdo y cruel" (1969, p. 439). Años más tarde, comienzan a examinarse sus zonas de contacto, sobre todo, los efectos perturbadores generados por el acto ritual:

Artaud y Triana nos hablan de un teatro en continua creación, donde la pieza escénica es un organismo que en los momentos de contacto con el público posibilita un acontecimiento ritual, que no se rige por los paradigmas de una estética aristotélica. (Barranco, 1997, p. 46)

De acuerdo con estas lecturas sobre el legado de Artaud en la obra de Triana y la configuración de la violencia, las elecciones formales de La noche de los asesinos exhiben una apertura del teatro cubano hacia exploraciones no miméticas sobre zonas prerracionales que desestabilizan las categorías de acción, personaje y lenguaje, en tanto el cuerpo adquiere protagonismo, en desmedro de la palabra hablada.
La obra pone en escena un juego siniestro practicado por los hermanos Lalo, Cuca y Beba que consiste en matar infinitamente a sus padres dentro del sótano de su casa. Los progenitores generan una atmósfera conservadora y asfixiante sobre sus hijos, a tal punto que estos desean la liberación por medio de la crueldad: el parricidio. La escenificación de la violencia, que afecta a las acciones, los objetos y las palabras, evidencia el modo en que Triana hace uso del programa artaudiano. El dramaturgo cubano evidencia esta apropiación al elegir una cita de El teatro y su doble como epígrafe: "este mundo humano entra en nosotros, participa en la danza de los dioses, sin retroceder, ni mirar atrás, so pena de convertirse como nosotros mismos: en estatuas de sal..." (Triana, 2016, p. 73). Para evitar convertirnos en pulverizados monumentos, como los objetos que duermen en los museos, es preciso rehacer una cultura que esté hecha a imagen de la vida. Por ello, el crimen despiadado contra los padres busca movilizar las entrañas del público para evitar que se convierta en un receptor pasivo, que solo cuestione la realidad desde el intelecto.

Además, los protagonistas sufren una multiplicación de la identidad, puesto que un mismo actor representa varios roles simultáneamente. Se pone en tela de juicio la noción tradicional de personaje en tanto unidad pero también la narración lineal al proponer una historia que vuelve a comenzar. De hecho, la obra inicia con Lalo, quien cierra la puerta del cuarto y grita que hay un asesino, por lo que sus hermanas le responden: "BEBA.- [...] La representación ha empezado. / CUCA.- ¿Otra vez? / BEBA.- [...] ¡Ni que esto fuera algo nuevo!" (Triana, 2016, p. 75). Al notar que el crimen ha sido representado numerosas veces, se hace evidente que los personajes están condenados a repetir este ritual macabro ad infinitum y que este asesinato no puede concretarse fuera del cuarto. La metateatralidad es, entonces, un eje central de la obra, en tanto permite producir un distanciamiento del afán realista y poner en relieve los aspectos teatrales del espectáculo al exagerar los comportamientos de los actores y desnudar la escenografía sugiriendo ese sótano como un espacio escénico.

El juego de espejos posibilita a los hermanos dejar salir sus contradicciones internas, su tendencia al crimen, hasta su canibalismo. Además del uso del te- 
atro dentro del teatro, La noche de los asesinos emplea el rito dentro del rito, esto es, los protagonistas representan un rito del asesinato que forma parte del juego metateatral en su "afán de escape y liberación de la realidad" (Zalacaín, 1985, p. 20). Y ese ritual emplea la violencia porque parece ser el único medio para erradicar lo viejo, lo impuesto, para crear una nueva realidad y recobrar así las libertades perdidas. Pero, como dijimos, el rito no concluye nunca puesto que Lalo, Cuca y Beba están condenadas a repetirlo una y otra vez. Esta reiteración cíclica del asesinato "suplementa la comunicación verbal con el auditorio, logrando el tipo de lenguaje calificado por Artaud como "equidistante entre el gesto y el pensamiento", (Zalacaín, 1985, p. 20).

De modo semejante a Medea en el espejo, se puede detectar en ciertas escenas donde los personajes interpretan a los vecinos Margarita y Pantaleón, sus padres, la policía o los jueces, una vinculación con las técnicas de los posesos o "montados", como explica Lydia Cabrera (2009, p. 30). Ello se pone de manifiesto hacia el final de la obra:

BEBA.- (Como LALO. Gritando y moviéndose en forma de círculo por el escenario.) Hay que quitar las alfombras. Vengan abajo las cortinas. La sala no es la sala. La sala es la cocina. El cuarto no es el cuarto. El cuarto es el inodoro.

(BEBA está en el extremo opuesto a LALO, de espaldas al público. LALO, también de espaldas al público, se va doblando paulatinamente. En un grito espantoso.)

Ayyyyy. (Entre sollozos.) Veo a mi madre muerta. Veo a mi padre degollado. (En un grito.) ¡Hay que tumbar esta casa! (Pausa larga.) (Triana, 2016, p. 127)

La posesión de Lalo, que lleva a que su cuerpo se doble hacia atrás y sus palabras se acompañen de gritos y expresiones de dolor y espanto, es lo que le permite tomar la decisión de cambiar el estado de las cosas, es decir, las órdenes impuestas por sus padres. En los rituales afrocubanos, la posesión de los médiums sirve de comunicación con los dioses y los muertos (Martiatu Terry, 1997, p. 123); en La noche de los asesinos, posibilita ver a sus padres muertos $\mathrm{y}$, así, trastornar el orden de las cosas. Es la opresión de los padres la que lleva a los personajes, agobiados, a desear un cambio del orden de las cosas, tal como se simboliza en la posición de los muebles de la casa. Lalo quiere colocar la silla en otra posición que la impuesta por sus padres. Sin embargo, el hermano no consiente a sus padres porque cree que sus órdenes son irracionales. Las autoridades de esa familia desean que todo permanezca inmóvil, que nada cambie, pero Lalo lucha para no ser reducido a la condición de títere u objeto, desea su libertad:

Yo quiero mi vida: $[. .$.$] para decir y hacer lo que$
deseo o siento. Sin embargo, tengo las manos
atadas. Tengo los pies atados. Tengo los ojos
vendados. Esta casa es mi mundo. Y esta casa se
pone vieja, sucia y huele mal. Mamá y papá son
los culpables. (Triana, 2016, p. 85)

Ataca el territorio de los padres por ser castrador y lo destruye para imponer otro, como se puede ver en el "estribillo" de la obra — "La sala no es sala. La sala es la cocina. El cuarto no es el cuarto. El cuarto es el inodoro" (2016, p. 119). Así, se pone de manifiesto que la ceremonia exorcista practicada por los hijos se constituye en un acto de liberación.

En el caso de La noche de los asesinos, es posible ver no solo la violencia ejercida por los hijos hacia los padres, sino también entre los mismos hermanos, quienes toman posturas antitéticas. Mientras que Lalo y Beba son quienes desean efectuar el crimen, Cuca defiende a sus padres, a pesar de que es cómplice del asesinato simbólico: "No puedes negar que siempre se han ocupado, que siempre te han querido" (Triana, 2016, p. 85); "Mamá y papá te lo han dado todo", "Todos los padres hacen lo mismo. Eso no significa que tú tengas que virar la casa al revés" (2016, p. 86); “Mamá y papá tienen razón" (2016, p. 87). La violencia, por ende, como señala Montes Huidobro, se construye a través de un parricidio y también de un cainismo: el primero puede ser leído como una rebelión contra la opresión y la dictadura a la que se ven sometidos los hijos, en especial, Lalo; el segundo crimen familiar revela una guerra civil que responde a posicionamientos ideológicos antagónicos.

Esta puesta en escena de la voracidad intrafamiliar ha sido leída en términos políticos. No obstante, también puede ser interpretada en diálogo con 
las tradiciones religiosas africanas. En efecto, Montes Huidobro pone de manifiesto el modo en que la familia cubana aparece en el teatro empujada por el canibalismo y trata de encontrar la génesis de esa característica en un sincretismo cultural de lo africano y lo cristiano. Esto lo lleva al análisis de la importancia de la liturgia negra y cristiana y de sus manifestaciones dentro de las creaciones dramáticas cubanas. Para el escritor cubano, la esencia mágica de toda religión es lo que permitió la integración de lo católico y lo afro, cuestión reconocible en La noche de los asesinos en los momentos en que los personajes representan a otros personajes, por ejemplo, la interpretación de sus vecinos, que lleva a la posesión de Lalo, quien expresa: "Fuera, fuera de aquí" (Triana, 2016, p. 83), como si estuviese apoderado por el "santo", de modo análogo al ritual yoruba.

Este distanciamiento de la representación mimética se acentúa en el plano lingüístico. Los personajes sufren una incomunicación a lo largo de la obra provocada por la superposición de temas, espacios y tiempos, los sobreentendidos, las oraciones incompletas, los silencios, las repeticiones y los rodeos verbales. Una de las problematizaciones del lenguaje
Para alcanzar este exorcismo, la crueldad también se construye a través de la música y los efectos sonoros, acompañados de una peculiar distribución espacial de los cuerpos. Por ejemplo, los hermanos antes y después de cometer el sacrificio llevan a cabo pequeños rituales: desplazan las sillas por el espacio escénico, manipulan cuchillos para hacerlos sonar, abren y cierran la puerta, golpean la mesa. Pero es durante el interrogatorio de los policías cuando se lleva al extremo la expresión musical de la obra al emplear sonidos vocálicos y taconeos acompasados. Los textos se pronuncian bajo la métrica del "tac-tac, tac-tac" dicho por Beba oralmente y acompañado de golpes percusivos que simulan el ruido de una máquina de escribir. Una acotación sostiene que la escena debe crear un "gran sentido rítmico" (Triana, 2016, p. 110) y que deben aprovecharse los recursos al máximo hasta lograr el "delirio". Mediante estas búsquedas sonoras, el lenguaje intenta expresar lo que habitualmente no expresa, tal como plantea Artaud.

El uso de todos estos recursos también es propio de la naturaleza espectacular, tal como identifica Fernando Ortiz en Los bailes y el teatro de los negros en el folklore de Cuba (1981 [1951]), sobre todo en los rituales de

\section{Más allá de los debates suscitados respecto de su condición de revolucionario o contrarrevo- lucionario, las dos piezas de José Triana analizadas en este artículo ponen en discusión los modos convencionales de hacer teatro en Cuba para finalmente proponer un espectáculo que apuesta por el cruce entre las mitologías occidentales y las mitologías afrocubanas.}

radica en el quiebre en la relación entre el decir y el hacer: los hermanos dicen que han matado a sus padres, pero ello no se concreta en el plano material. Por consiguiente, exhiben la vacuidad de las palabras y la imposibilidad de concretar el asesinato. Ese rodeo lingüístico es construido discursivamente en diversos planos — sintáctico, fonético y semántico - y, a su vez, afecta las voces de los personajes. La inutilidad de la palabra, su impostura e impotencia, nos lleva a entablar un diálogo con la propuesta de Artaud, quien no busca producir climas ominosos a través de la palabra, puesto que, para el escritor francés, "expresar todo sentimiento es traicionarlo, en tanto es intraducible" (2014, p. 76). Mediante esta decisión estética, escapando del dominio de la palabra, intenta provocar un vacío en el pensamiento del espectador.
Santería, el Palomonte, la Sociedad Secreta Abakuá, el Vodú, el Bembé de Sao y el espiritismo, que llevan a cabo descomunales actuaciones de los médiums o "caballos", así como es posible reconocer un teatro total que cruza los lenguajes de la danza, la poesía, la música, la pantomima, la acrobacia, el vestuario y las máscaras, escenografía, pintura, escultura (Martiatu Terry, 1997, p. 122). Las ceremonias de los sistemas mágico-religiosos tienen una teatralidad que se aproxima a lo que Artaud denomina "poesía del espacio". Todos estos componentes propios de los recintos sagrados caribeños se ponen a funcionar en la puesta en escena de La noche de los asesinos, tal como sugieren las didascalias y los diálogos de los personajes.

La recepción de la obra de Triana en Cuba ha sufrido variaciones de acuerdo con el paso del tiempo 
y el proceso de radicalización de la política cultural del régimen. A pesar de haber recibido en 1965 el Premio Casa de las Américas, Triana comenzó a ser acusado de desviacionista ideológico por los periódicos, lo que culmina en su salida del país hacia 1980. Además, su participación como jurado del premio "José Antonio Ramos" de teatro, edición 1968 convocado por la Unión de Escritores y Artistas de Cuba (UNEAC) - que dio como ganador a Los siete contra Tebas de Antón Arrufat, junto con Fuera de juego de Heberto Padilla, genera un quiebre en la crítica nacional, puesto que empiezan a considerar sus obras opositoras al pensamiento de la Revolución, en especial, por escoger la ambigüedad discursiva. De modo semejante a la lectura que se hizo de Arrufat, rechazan el uso de poéticas extranjeras provenientes de Ionesco, Beckett, Genet, por ser leídas como signo de colonización cultural y desligadas de la realidad nacional. En este marco de debates sobre la posición que debe ocupar el teatro en relación con la política, se desarrollan los trabajos críticos sobre José Triana, especialmente preocupados por el problema de su (in) dependencia cultural respecto del arte foráneo. En efecto, La noche de los asesinos ha sido interpretada o bien como una alegoría de la dictadura de Batista y como un testimonio de un pasado sufrido y, por ende, defensora de la causa revolucionaria (Miranda, 1969), o bien como una denuncia cifrada de la Revolución, cuya tesis sería que la historia cubana es cíclica: una dictadura reemplaza a otra ad infinitum (Nigro, 1977).

\section{Conclusiones}

Más allá de los debates suscitados respecto de su condición de revolucionario o contrarrevolucionario, las dos piezas de José Triana analizadas en este artículo ponen en discusión los modos convencionales de hacer teatro en Cuba para finalmente proponer un espectáculo que apuesta por el cruce entre las mitologías occidentales y las mitologías afrocubanas. De este modo, redefine el teatro local y dominante, en tanto este ya no se edifica a partir de razonamientos lógicos y psicológicos, sostenidos en el logocentrismo, sino que se encuentra atravesado con otras formas estéticas y, por ende, con nuevas perspectivas ideológicas que recrean el lenguaje y recuperan su poder de acción extendiendo los límites de la realidad. Continuar el legado de Artaud a través del regreso a rituales macabros provenientes de las religiones africanas implica "resquebrajar los símbolos realizados de la cultura" (Artaud, 2014, p. 28), exponer la crueldad latente del individuo con el objetivo de afectar físicamente al público y, con ello, interrogar sus concepciones sobre la realidad.

Una de las concepciones cristalizadas en la sociedad cubana de los años sesenta es la asociación de la cultura afro con la superstición, la brujería, la magia y la animalidad, condiciones que supuestamente lleva a esta comunidad a cometer crímenes despiadados y voraces incluso dentro de su seno familiar. Pero en estas obras se expone, a través de sus temáticas y, en especial, de sus elecciones formales, que lo que impulsa a estos personajes a cometer estos crímenes es una necesidad de liberación frente a las autoridades en términos familiares, políticos y religiosos. Se tratan de actos de resistencia cultural contra la hegemonía blanca y neocolonial.

De ahí podemos interpretar la desestabilización que provocaron las obras de Triana respecto de las categorías tradicionales sobre el arte, tanto en el público como en la crítica nacional e internacional. Respecto del arte, se transgreden las formas convencionales de representación, en tanto el discurso hablado se ve afectado por la danza y el ritmo cuyo origen es mágico, lo que implica también una relación diferente con el público, cuyo intelecto no le servirá para interpretar los sucesos representados. Entre el teatro sagrado y el teatro profano, entre el rito y la representación teatral, entre el pensamiento mítico y el pensamiento lógico, entre la realidad y la ficción, las obras también trastocan estructuras sociopolíticas cristalizadas que ocultan la discriminación étnica, aún persistente durante la Cuba posrevolucionaria. Nuevamente, la religiosidad africana, con su música y danza, se inserta en el espectáculo teatral, aunque en lugar de hacerse mediante la deformación o ridiculización, ahora resulta ser un arma de conservación y defensa de una cultura históricamente sometida a la opresión. 


\section{NOTAS}

1 Como sostiene Manuel Moreno Fraginals, en toda forma de explotación colonial se lleva a cabo un proceso de deculturación, es decir, de desarraigo de la cultura de un grupo humano para facilitar la expropiación de las riquezas naturales de un territorio, aunque la deculturación total es imposible. En tal sentido, "a los explotadores no les interesa hacer tabla rasa de los valores culturales de la clase explotada, sino sólo de aquellos elementos que obstaculizan el sistema de explotación establecido. Es normal, inclusive, que la clase dominante proteja y aun estimule el desarrollo de valores culturales aislados de la clase dominada siempre que éstos contribuyan a reforzar la estructura establecida" (1987, p. 14). Permitir a los esclavos que practiquen ciertos rituales de su religiosidad africana ha sido una estrategia para mantener el statu quo, igual que lo realizado con los carnavales medievales europeos (Bajtín, 2005).

2 María Antonia pone en escena a personajes de un barrio marginal negro de La Habana que hablan en lengua yoruba y practican ritos de santería. Expone, a su vez, que el racismo no es un tema del pasado ya superado, sino que continúa en la sociedad cubana posrevolucionaria. Debido a que la crítica oficial la ha calificado como contrarrevolucionaria, la obra fue cancelada un año después de su estreno y su elenco es perseguido, a pesar de que ninguno de sus protagonistas ha estado involucrado en actos de disidencia contra el Estado de Fidel, como señala Lilian Guerra (2014).

3 Los mitos griegos han sido retomados por varias obras cubanas entre las décadas de 1940 y 1960. Una de las más conocidas es Electra Garrigó de Virgilio Piñera, escrita en 1941, donde ya puede verse una tensión entre la importación de elementos extranjeros y la incorporación de lo autóctono. Por otro lado, Los siete contra Tebas (1968) de Antón Arrufat es otra de las más estudiadas por la crítica, dado que despertó fuertes polémicas al recibir, junto con Fuera de juego de Heberto Padilla, el premio de la Unión de Escritores y Artistas de Cuba (UNEAC), cuyo jurado estuvo conformado por José Triana, entre otros. Ambas obras fueron consideradas opositoras al pensamiento de la Revolución por escoger la ambigüedad discursiva y por hacer uso de poéticas extranjeras provenientes de la tragedia griega pero también de lonesco, Beckett, Genet, lo que fue leído como signo de colonización cultural y desligado de la realidad nacional. Si bien ya desde las "Palabras a los intelectuales" pronunciadas por Fidel Castro en 1961, donde sostiene: "Dentro de la Revolución, todo; contra la Revolución, nada", la radicalización ideológica respecto de la función social del arte y el teatro se hace ostensible con el caso Padilla y las declaraciones de la UNEAC. En este marco de debates sobre la posición que debe ocupar el teatro en relación con la política, se desarrolla la obra de José Triana. Por ende, su producción está afectada por el problema "la cubanía" y su (in)dependencia cultural respecto al arte occidental.

4 La descripción de los personajes expresa la heterogeneidad social y étnica de Cuba, metaforizada muchas veces a partir del plato nacional "ajiaco": "En nuestra peculiar 'olla podrida' se cuecen y asimilan en el hervor y el sabor la carne de puercos que descienden de aquellas famosas 'ocho hembras del Almirante / que a las Indias vinieron en la Marigalante y en las Indias hozaron la doncellez del fango' (según versos famosos de Llorens Torres), junto con la yuca y el maíz que legaron los pobres indios desaparecidos, el plátano que llegó del África Occidental y muchos otros ingredientes de las más variadas procedencias. Si hay un plato mestizo, ése es el ajiaco" (Castellanos y Castellanos, 1994, p. 18).

5 Este tratamiento sonoro del lenguaje ha sido trabajado por la poesía negra de los años 30 y 40, con Nicolás Guillén como máximo exponente. Sus textos vanguardistas, como el poemario Sóngoro Cosongo (1931), exploran la cultura del negro tanto en lo temático como en lo formal. Este mundo afroamericano se construye discursivamente a partir de imágenes auditivas y el uso de abundantes figuras de dicción, lo que provoca que sus poemas sean denominados "poemas-son", debido a la traducción del género musical cubano al lenguaje poético.

6 A su vez, James destaca otros crímenes practicados por los esclavos, como envenenar a los hijos de su amo: "los esclavos envenenaban a los hijos más pequeños de un amo para asegurarse de que la plantación pasaba a las manos 
de un hijo en particular. De esta forma, impedían que la plantación se disgregase y la cuadrilla de esclavos se dispersara. En determinadas plantaciones los esclavos diezmaron con veneno a muchos para mantener reducido el número de esclavos e impedir que los amos se embarcasen en ambiciosas empresas que incrementarían su carga de trabajo. Por esta razón, un esclavo podía envenenar a su esposa, otro a sus hijos, y una niñera negra declaró ante los tribunales que durante años estuvo envenenando a todos los niños que había traído a este mundo" (2003, pp. 31-32). De acuerdo con sus datos, la enfermedad de mandíbula provocó la muerte de casi un tercio de los niños nacidos en las plantaciones.

7 Heladio Colín Medina (2019) ha realizado un aporte significativo a los estudios sobre La noche de los asesinos al centrar su análisis en el tema del doble, objeto obliterado por la crítica especializada en la obra de José Triana. Desde las perspectivas teóricas de Otto Rank, Juan Bargalló y Francisco Durán, observa la existencia de dos niveles de actuación -los diálogos entre los hermanos y su desdoblamiento en varios personajes-, lo que evidencia la construcción de un "yo ideal" o "doble soñado" (p. 17) por parte de la tríada para liberar al "yo real" de la tiranía paterna y la mediocridad social. No son los personajes sino sus dobles quienes asesinan a sus padres, dado que su sumisión no les permite concretar el crimen en el plano de la realidad. En otras palabras, descargan en el "otro yo" los deseos ocultos, reprimidos, como el parricidio. Si bien Colín Medina se ocupa de La noche de los asesinos, podríamos pensar que el motivo del doble también opera en Medea en el espejo, en tanto su protagonista, como observamos anteriormente, duplica su figura a través de su reflejo en el espejo, forma de desdoblamiento recurrente en la literatura fantástica, como ya señala Otto Rank (2004 [1914]). Siguiendo la categorización de Juan Bargalló, recuperada por el investigador mexicano, se trataría de una "fisión", en tanto de María nacen "dos personificaciones del que originalmente no existían más que uno" (1994, p. 17). Nuevamente, la protagonista de Triana debe construir un "otro yo" que cometa el crimen por ella y logre, así, su emancipación.

8 El plano metateatral de La noche de los asesinos, en el que los hermanos devienen actores que representan otros personajes, puede ser leído como una farsa. Ello se debe a que Lalo, Cuca y Beba introducen elementos de este género teatral, como actuar personajes típicos, hacer uso de las payasadas, muecas, equívocos verbales, con el objetivo de generar una comicidad grotesca y bufonesca (Pavis, 2011, p. 205). Estos componentes resultan notorios en los diálogos de los vecinos y en la representación de la boda. Retomar dicha tradición teatral conlleva no solo hacer uso de sus temáticas y formas, sino también apropiarse de su función subversiva respecto de las instituciones morales y políticas, propia de la farsa antigua y medieval, como ha señalado Bajtín (2005). A través de la risa liberadora, la obra de Triana parece denunciar la hipocresía social o, lo que mencionamos en la anterior nota, la "mediocridad del ambiente" (cfr. Colín Medina, 2019).

9 Según Inés María Martiatu Terry, nace en Cuba una técnica de actuación que lleva a que el actor encuentre recursos en sí mismo, en una experiencia personal o ancestral que le es propia. A través del trance, el sujeto logra una ampliación de la conciencia. En este caso, los personajes de Triana llegan a ese estado por la exacerbación lograda mediante el ritmo, la danza y la música, una de las formas posibles empleadas "en las fiestas de Santería" (Martiatu Terry, 1997, p. 127) para lograr la posesión.

10 Martiatu Terry propone la noción de "teatro ritual caribeño", en lugar de teatro antropológico o etnodrama, promovido por el teatro de las fuentes de Grotowski - la antropología teatral de Eugenio Barba, puesto que sostiene la necesidad de nombrar a un movimiento de teatro ritual en el Caribe aparecido en Cuba. Utiliza dicha noción desde la perspectiva de la transculturación (Ortiz) "porque define su carácter y las funciones que cumple tanto en el teatro que llamo sagrado (ceremonias religiosas), como en el profano (representan en espacios teatrales convencionales o no)" y, por otro lado, emplea el término caribeño para referirse a lo que va más allá de lo geográfico, es decir, al "mestizaje con el componente africano, religiones sincréticas de origen africano, magia, carnaval, música, etc." (1997, p. 124). 


\section{Referencias bibliográficas}

Artaud, A. (2014 [1938]). El teatro y su doble. Buenos Aires: El Cuenco de Plata.

Bajtín, M. (2005 [1933]). La cultura popular en la edad media y en el renacimiento. El contexto de François Rabelais. Madrid: Alianza.

Bargalló, J. (1994). Identidad y alteridad. Aproximaciones al mito del doble. Sevilla: Alfar.

Barranco, J. (1997). Artaud y La noche de los asesinos. Encuentro, 4-5, 46-52. http://arch1.cubaencuentro.com/pdfs/4-5/4jb46.pdf

Cabrera, L. (2009 [1954]). El monte, igbo finda, ewe orisha, vititinfinda: notas sobre las religiones, la magia, las supersticiones y el folklore de los negros criollos y el pueblo de Cuba. La Habana: Letras Cubanas.

Castellanos, J. y Castellanos, I. (1988). Cultura Afrocubana. Miami: Universal.

Castro, F. (1961). Palabras a los intelectuales. La Habana: Ediciones del Consejo Nacional de Cultura.

Colín Medina, H. (2019). La noche de los asesinos, de José Triana: una mirada desde el doble. Tonos digital. Revista de estudios filológicos, 37, 1-26.

https://digitum.um.es/digitum/bitstream/10201/74350/1/tintero-2-colin_la_noche.pdf

Cornejo-Polar, A. (2003 [1994]). Escribir en el aire. Ensayo sobre la heterogeneidad sociocultural en las literaturas andinas. Lima: Centro de Estudios Literarios Antonio Cornejo Polar.

De la Campa, R. (1979). José Triana: ritualización de la sociedad cubana. Mineápolis: Institute for the Study of Ideologies and Literature.

Dos Santos, J. E. y Dos Santos, D. M. (1987). Religión y cultura negra. En M. Moreno Fraginals, África en América Latina (2. ${ }^{a}$ ed.) (pp. 103-129). Ciudad de México: Siglo Veintiuno Editores.

Escarpenter, J. A. (1994). Elementos de la cultura afrocubana en el teatro de José Triana. En K. Nigro (Comp.), Palabras más que comunes. Ensayos sobre el teatro de José Triana (pp. 33-41). Colorado: Society of Spanish and Spanish-American Studies.

Eurípides. (2015). Medea. Introducción, traducción y notas de Elsa Rodríguez Cidre. Buenos Aires: Losada.

González, P. E. (1997). Presencia de la cultura negra en el teatro cubano contemporáneo. Tramoya, 53, 28-38. http://cdigital.uv.mx/handle/123456789/4301

Guerra, L. (2014). Raza, negrismo, y prostitutas rehabilitadas: revolucionarios inconformes y disidencia involuntaria en la Revolución Cubana. América sin nombre, 19, 126-139. https://doi.org/10.14198/AMESN.2014.19.14

James, C.L.R. (2003 [1938]). Los jacobinos negros. Toussaint L'Ouverture y la Revolución de Haití Traducción de Ramón García. Madrid: Fondo de Cultura Econímica.

Leal, R. (1975). Teatro bufo siglo XIX. Antología, tomo I. La Habana: Ed. Arte y Literatura.

Leal, R. (1980). Breve historia del teatro cubano. La Habana: Letras Cubanas.

Lobato Morchón, R. (2002). El teatro del absurdo en Cuba (1948-1968). Madrid: Verbum.

Martiatu Terry, I. M. (1997). Un teatro ritual caribeño en Cuba. Tramoya, 3, 122-128. https://cdigital.uv.mx/bitstream/handle/123456789/4253/199751P122. pdf? sequence $=2$

Miranda, J. E. (1969). José Triana o el conflicto. Cuadernos Hispanoamericanos, 230, 439-444. http://www.cervantesvirtual.com/nd/ark:/59851/bmc3n2m6

Montes Huidobro, M. (1973). Persona, vida y máscara en el teatro cubano. Zaragoza: Cometa.

Moreno Fraginals, M. (1987). Aportes culturales y deculturación. En M. Moreno Fraginals, África en América Latina (pp. 13-34). Ciudad de México: Siglo Veintiuno Editores.

Nigro, K. F. (1977). La noche de los asesinos: Playscript and Stage Enactment. Latin American Theatre Review, 11 (1), 45-57. http://www.cervantesvirtual.com/nd/ark:/59851/bmc1n8m8 
Ortiz, F. (1975). Nuevo cantauro de cubanismos. La Habana: Editorial de Ciencias Sociales.

Ortiz, F. (1981 [1951]). Los bailes y el teatro de los negros en el folklore de Cuba. La Habana: Letras Cubanas.

Ortiz, F. (1987 [1940]). Contrapunteo cubano del tabaco y del azúcar. Caracas: Biblioteca Ayacucho.

Ortiz, F. (1995 [1906]). Los negros brujos. La Habana: Editorial de Ciencias Sociales.

Pavis, P. (2011). Farsa. En Diccionario de teatro. Dramaturgia, estética, semiología. Buenos Aires: Paidós.

Rank, O. (2004 [1914]). El doble. Buenos Aires: Orión.

Triana, J (2016 [1965]). La noche de los asesinos (4. ${ }^{a}$ ed.). Madrid: Cátedra.

Triana, J. (2004 [1960]). Medea en el espejo. Assaig de teatre: Revista de I'associació d'investigació i experimentació teatral, 42, 89-124. https://core.ac.uk/download/pdf/39115467.pdf

Urfé, O. (1987). La música y la danza en Cuba. En M. Moreno Fraginals (Comp.), África en América Latina (pp. 215-237). Ciudad de México: Siglo Veintiuno Editores.

Vastey, J. L. (2018 [1814]). El sistema colonial develado. Edición y estudio preliminar de Juan Francisco Martínez Peria. Traducción de Laura Léger. Buenos Aires: Ediciones del Centro Cultural de la Cooperación Floreal Gorini.

Zalacaín, D. (1985). El asesinato simbólico en cuatro piezas dramáticas hispanoamericanas. Latin American Theatre Review, 19 (1), 19-26. https://journals.ku.edu/latr/article/view/614 